\title{
STRATEGIES OF CRITICAL THINKING DEVELOPMENT IN THE DIDACTICS OF INFORMATICS
}

\author{
[STRATEGIE ROZVOJA KRITICKEHO MYSLENIA V DIDAKTIKE \\ INFORMATIKY]
}

\section{Gabriela Lovaszova}

doi: 10.18355/PG.2018.7.1.13

\begin{abstract}
Critical thinking provides the ability to interpret, analyze and evaluate the quality of information and thinking procedures (own or others' ones), based on this, to formulate attitudes, present and justify conclusions. It would seem, the digital world with freedom to access a great deal of information provides people with ideal conditions for cognitive skills development that represent a basic part of critical thinking. However, the experience shows more an opposite trend. In this paper, we present the way of how the lessons of informatics may contribute to the development of cognitive skills and personal predispositions of critically thinking human being in a society where digital technologies play an important role, as well as, certain methods of critical thinking development in the didactical training of future teachers of informatics.
\end{abstract}

\section{Key word}

critical thinking, creative thinking, thoughts structuring, creative environment, collaborative environment

\begin{abstract}
Anotácia
Kritické myslenie poskytuje schopnost' interpretovat', analyzovat' a hodnotit' kvalitu informácií a myšlienkových postupov (vlastných alebo cudzích), na základe toho formulovat' úsudky, prezentovat' a obhajovat' závery. Zdalo by sa, že v digitálnom svete so slobodným prístupom k množstvu informácií majú l'udia ideálne podmienky na rozvoj kognitívnych spôsobilostí, ktoré tvoria jadro kritického myslenia. Avšak skúsenosti naznačujú skôr opačný trend. V príspevku predstavíme, ako môže vyučovanie informatiky prispievat' k rozvoju kognitívnych spôsobilostí a osobnostných dispozícií kriticky mysliaceho človeka v spoločnosti, v ktorej digitálne technológie zohrávajú významnú úlohu, a niektoré metódy rozvoja kritického myslenia v didaktickej príprave študentov učitel'stva informatiky.
\end{abstract}

\section{Kl'účové slová}

kritické myslenie, tvorivé myslenie, štruktúrovanie myšlienok, tvorivé prostredia, kolaboratívne prostredia

\section{Úvod}

Kriticky mysliaci človek je človek s otvorenou mysl'ou, prirodzene zvedavý, flexibilný, chápajúci rozmanité hl’adiská, hl'adajúci argumenty pre formuláciu 
konečných rozhodnutí, odmieta povrchnost', pred prijatím záverov vždy zvažuje dôkazy bez ohl'adu na to, kto je ich nositel'om (Ruisel, 2005).

$\mathrm{V}$ digitálnom svete so slobodným prístupom $\mathrm{k}$ množstvu informácií majú žiaci vhodné podmienky na rozvoj kognitívnych spôsobilostí, ktoré tvoria jadro kritického myslenia. Môžu vyhl'adávat' a overovat' si informácie z rôznych zdrojov, vytvárat' vlastné úsudky na základe nefiltrovaných informácií, prezentovat' svoje závery, argumentovat' v on-line prostredí. Avšak skúsenosti naznačujú skôr opačný trend. Ponúka sa príliš vel'a dostupných informácií. Frustrácia, ktorá vzniká z pocitu, že nie je možné preskúmat' a zhodnotit' všetky, vedie k povrchnosti a skepse, ktorá je v protiklade s osobnostnými dispozíciami spojenými s kritickým myslením.

Okrem frustrácie z pretlaku informácií môže mat' vplyv na sklony $\mathrm{k}$ povrchnosti aj používanie digitálnych technológií nevhodným spôsobom:

- Pri hodnotení prijímaných informácií: Žiak dôveruje neomylnosti softvéru a hardvéru, tento pocit dôvery sa prenáša aj na údaje bez ohl'adu na ich zdroj.

- Pri spracovávani informácií: Efektívnost' šírenia, kopírovania, upravovania, spracovávania digitálnych dát pomocou počítača zvádza žiaka k jednoduchým a rýchlym riešeniam bez hlbšieho premýšl'ania.

- Pri argumentácii: Anonymita on-line prostredia zvádza k povrchnej argumentácii založenej na afektoch namiesto objektívneho podrobného zvažovania dôkazov, argumentov.

Dôležitým ciel'om vyučovania informatiky je naučit' žiakov používat' digitálne technológie kvalifikovanejšie. Namiesto zneužívania digitálnych technológií na zjednodušovanie si práce (čo môže viest' k stagnácii až k úpadku myslenia) je ciel'om používat' technológie spôsobom, ktorý využíva výhody digitálneho prostredia na skvalitnenie kritického myslenia. Získavanie poznatkov o princípoch a limitoch počítačového spracovania dát je jedným zo spôsobov, ako kultivovat' používanie digitálnych technológií. Vedomosti z informatiky nám umožňujú pracovat' s digitálnymi technológiami kvalifikovane, s porozumením, na základe vlastných úsudkov, namiesto práce podl'a návodov a slepej dôvery v neomylnost' počítačov a správnost' dát.

Otvorená mysel', flexibilita a d'alšie osobnostné dispozície kriticky zmýšlajúceho človeka sú základom pre rozvoj tvorivosti, vytváranie vlastných riešení s rôznym stupňom originálnosti. Väčšina odborníkov sa priklán̆a k názoru, že kritické myslenie a tvorivost' sú neoddelitel'né a vo výučbe ich treba rozvíjat' paralelne. Vysoký stupeň konštruktivizmu v metódach typických pre vyučovanie informatiky vytvára podmienky na rozvoj tvorivosti, a tým aj kritického myslenia.

\section{Metódy rozvoja kritického myslenia a tvorivosti}

Jadro kritického myslenia tvoria dve dimenzie (Facione, 2015; Duchovicova a Tomsik, 2017):

- kognitívne spôsobilosti: interpretácia, analýza, hodnotenie, usudzovanie, vysvetl'ovanie, sebaregulácia,

- osobnostné dispozície: široký okruh záujmov, snaha byt' dobre informovaný, dôvera v silu rozumu a vlastný úsudok, otvorenost' mysle,

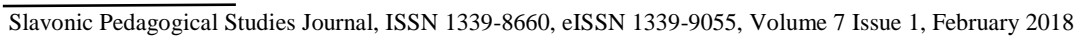


nezaujatost', opatrnost' pri utváraní záverov, ochota priznat' si egocentrické sklony, predsudky, vlastné chyby, ochota prehodnotit' vlastné stanovisko.

Pri rozvíjaní kritického myslenia je potrebné cielene zamerat' pozornost' na obe dimenzie. Človek s kognitívnymi spôsobilostami bez osobnostných dispozícií potrebných pre kritické myslenie môže podliehat' rôznym pseudovedeckým názorom a teóriám, ktoré používajú logickú argumentáciu, ale zaujato a bez širšieho kontextu. Na rozvoj osobnostných dispozícií má pozitívny vplyv tvorivá činnost'. Je zdrojom cenných skúseností a pozitívnych emócií, pomáha budovat' pracovné návyky, rozširuje okruh záujmov.

V štúdii autorov Duchovicová a Tomsik (2017) sú identifikované klúčové vyučovacie stratégie uplatňujúce kognitívne orientovaný prístup pre rozvoj kritického a tvorivého myslenia: stratégie na rozvoj sebaregulácie, stratégie na rozvoj systematických a interpretatívnych zručností, stratégie argumentácie, stratégie pre vyvodzovanie záverov a riešenie problémov, stratégie na rozvoj hodnotenia a stratégie na rozvoj čitatel'ských zručností. Identifikácia týchto vyučovacích stratégií vytvára základ pre tvorbu inovatívnych metodík vodborovej didaktike s ciel'om rozvíjat' kritické a tvorivé myslenie študentov učitel'stva.

\section{Inovatívne metodiky $\mathbf{v}$ príprave študentov učitel'stva informatiky}

$\mathrm{V}$ didaktickej príprave budúcich učitel'ov informatiky sme sa zamerali na uplatňovanie stratégií pre rozvoj kritického myslenia a tvorivosti predovšetkým v súvislosti s digitálnou gramotnost’ou, algoritmickým a informatickým myslením $v$ oblastiach:

- štruktúrovanie myšlienok a vyjadrenie znalostí - rozvíjajú hlavne kognitívne spôsobilosti kritického myslenia: systematické a interpretatívne zručnosti, schopnost' reflexie, vyvodzovanie záverov,

- riešenie problémov a práca $\mathrm{v}$ tvorivých prostrediach - tvorivá činnost' vytvára vhodné prostredie pre rozvoj osobnostných dispozícií kriticky mysliaceho človeka,

- práca v kolaboratívnych prostrediach - kolaboratívne učenie sa je účinný prostriedok pre rozvoj rozhodovania a argumentačných zručností, pre rozširovanie vlastných skúseností poznávaním a zdiel'aním skúseností iných.

\section{Štruktúrovanie myšlienok a vyjadrenie znalostí}

Schopnosti štruktúrovat' myšlienky, systematicky pracovat' s informáciami a explicitne vyjadrit' znalosti $v$ zrozumitel'nej forme sú kognitívne spôsobilosti nevyhnutné pre pedagogickú prácu učitel’a. V didaktickej príprave budúcich učitel’ov sa na ich rozvíjanie dajú použit' rôzne stratégie: identifikácia a vymedzenie základných pojmov a vzt’ahov, využívanie kategorizácií, asociácií, metafor, vedenie k práci s textom, tvorba učebných materiálov pre žiakov, využívanie diskusie ako priestoru pre prezentovanie a skúmanie názorov študentov.

$\mathrm{V}$ príprave študentov učitel'stva informatiky sme sa $\mathrm{v}$ dvoch kolaboratívnych aktivitách zamerali na tvorbu poznámok a vymedzovanie pojmov. Cielom 
tvorby poznámok je štruktúrovanie a systemizácia poznatkov formou stručných, prehl'adných, odborne správnych poznámok vystihujúcich podstatu prebraného učiva. Ciel'om presného vymedzovania pojmov je kriticky sa zamýšl'at' nad vlastným chápaním pojmov, uvažovat' o ich význame do híbky a v rôznych kontextoch, odstraňovat' povrchnost', nepresnost', vágnost' vo vyjadrovaní, ktoré komplikujú komunikáciu so žiakom.

\section{Aktivita Tvorba poznámok}

V prvej aktivite študenti inscenovali vyučovacie hodiny programovania: jeden študent v roli učitel'a, ostatní v roliach žiakov. Študenti v roliach žiakov mali za úlohu priebežne si písat' poznámky z vyučovania. Vzorové učitel'ské poznámky pripravoval študent v roli učitel'a ako súčast' svojej prípravy na vyučovaciu hodinu.

Zhodnotenie modelových vyučovacích hodín s poznámkovaním:

- Poznámky študentov v roli žiakov: Vo vyučovaní programovania sa väčšinou uplatňuje problémové vyučovanie a prevládajúcou metódou je riešenie úloh, ktoré si vyžaduje aktívnu činnost' žiakov na počítači. Na poznámkovanie väčšinou nebol vytvorený dostatočný priestor medzi riešeniami úloh alebo pri záverečnom zhrnutí učiva. Napriek tomu, že obsah vyučovacej hodiny nebol pre študentov nový a učivo ovládali (na rozdiel od žiakov, ktorých pri inscenovaní vyučovacej hodiny hrali), poznámky mali nízku kvalitu. Naše skúsenosti teda naznačujú, že tvorba kvalitných poznámok $\mathrm{z}$ takéhoto typu učiva bez dostatočného času na reflexiu je pre žiakov vel'mi náročná. Reálnejšie ako systematické spoznámkovanie učiva počas hodiny žiakmi sa javí jednoduchý záznam hodiny vo forme riešení úloh.

- Poznámky študentov v roli učitel'a: Študenti v roli učitel'a písali poznámky $\mathrm{v}$ rámci svojej prípravy na vyučovaciu hodinu a mali preukázat' schopnost' odborne a metodicky správne vyjadrit' podstatu učiva zrozumitel'ným spôsobom. Študenti mali problémy so štýlom (používali štýl pre ústny prejav), s výstižnost'ou (písali záznam hodiny a nie zhrnutie podstatných prvkov učiva), s prehl'adnost'ou (používali nevhodné formátovanie, málo grafických prvkov).

- Tvorba poznámok je pre žiaka náročná úloha, lebo počas vyučovania nemusí mat' ešte dostatočný vhl'ad, aby vedel správne vystihnút', čo je a čo nie je podstatné, a odborne správne formulovat' myšlienky. Znalosti bývajú spočiatku neuvedomované, explicitne nevyjadritel'né, viazané na jeden kontext. Reálne je od žiaka očakávat' záznam hodiny. Pomoc učitel'a pri tvorbe systematických poznámok je preto vel'mi dôležitá.

\section{Aktivita Slovník pojmov}

Pri písaní poznámok sa prejavili u študentov aj problémy s vyjadrovaním. Vyjadrovacie schopnosti zahŕňajú schopnost' jasne definovat' pojmy, parafrázovat', používat' vhodné metafory, analógie, asociácie, vysvetl'ovat'. Pritom je dôležité vyhýbat' sa citovo zafarbeným slovám, vágnym a viacznačným vyjadreniam. Pokusy s presným definovaním pojmu často odhalia nedostatky $\mathrm{v}$ jeho chápaní, ktoré sa zakrývajú opisným vysvetl'ovaním. 
V druhej aktivite bližšie opísanej v štúdii (Michalickova - Lovászova, 2014) mali študenti učitel'stva informatiky spoločne zostavit' slovník pojmov $\mathrm{z}$ detského programovacieho jazyka Logo $\mathrm{v}$ kolaboratívnom elektronickom prostredí (modul Glossary systému Moodle). Po seminári programovania v Logu mali definovat' význam aspoň jedného nového pojmu z hodiny. $\mathrm{Na}$ nasledujúcom seminári si vytvorené definície navzájom kriticky hodnotili v diskusii. Kritický názor iného študenta pomáha rozšírit kontext, v ktorom sa o pojme uvažuje, odhalit' chyby $\mathrm{v}$ definícii, resp. nedostatky vo vyjadrovaní, ktoré môžu viest' $\mathrm{k}$ nesprávnemu pochopeniu pojmu, a tým celkovo skvalitnit' vymedzenie pojmu.

Zhodnotenie Tvorby slovníka: Chyby v príspevkoch možno kategorizovat' na:

- Prekoncepty, naivné formulácie. Definície vyjadrovali niektoré, ale nie všetky podstatné charakteristiky pojmu. Takéto formulácie odzrkadl'ujú predstavy o pojme zodpovedajúce skúsenostiam študentov. Sú prirodzenou fázou $\mathrm{v}$ konštruktívnom poznávacom procese, chápanie pojmu sa prehlbuje a upresňuje so získavaním d’alších skúseností.

- Miskoncepcie, nesprávne formulácie. Definície obsahovali tvrdenia, ktoré nie sú pravdivé. Odhal'ujú nepochopenie pojmu alebo problémy s vyjadrovaním myšlienok.

- Alternatívne pohl'ady. Príspevky nemožno považovat' za nesprávne, avšak definície nie sú systematické, a preto môžu mat' negatívny vplyv na budovanie konceptuálnej štruktúry poznatkov.

- Formálne nedostatky. Príspevky nezodpovedali dohodnutým pravidlám formátovania a štruktúrovania hesiel v slovníku. Výsledný spoločný slovník, na ktorom študenti spolu pracovali, bol formálne nesúrodý.

Skúsenosti s tvorbou slovníka naznačujú, že vyjadrovacie schopnosti študentov sú ich slabou stránkou a je potrebné ich rozvíjat'. Množstvo formálnych nedostatkov pri nedodržiavaní jednoduchých pravidiel formátovania, ktoré sú pri kolaboratívnej tvorbe spoločného diela popri obsahu takisto dôležité, svedčí o povrchnom prístupe študentov $\mathrm{k}$ práci. Dôraz na plnenie formálnych kritérií je účinným spôsobom vedenia študentov k dôkladnosti ako dôležitej osobnostnej dispozície kriticky mysliaceho človeka.

\section{Riešenie problémov a práca $\mathrm{v}$ tvorivých prostrediach}

Pre vyučovanie informatiky je typický vysoký stupeň konštruktivizmu. Žiak vel'a tvorí (textové dokumenty, tabul'ky, grafy, obrázky, prezentácie, videá, multimediálne dokumenty, webové stránky, programy) a získava vedomosti a zručnosti na základe skúseností z tvorivej činnosti. Používa pri tom softvérové aplikácie určené na tvorbu. Môžu to byt' štandardné softvéry na vytváranie a úpravu (editovanie) dát rôzneho typu, alebo špeciálne didaktické aplikácie.

Symbolom tvorivých prostredí určených špeciálne pre vzdelávanie je programovací jazyk Logo. Predstavuje takú myšlienku učenia sa s využitím digitálnych technológií, v ktorom sa žiak $\mathrm{v}$ interakcii $\mathrm{s}$ počítačom učí experimentovaním, tvorí.

Jedným z predstavitel’ov softvérových nástrojov založených na paradigme Logo je detské programovacie prostredie Scratch (https://scratch.mit.edu/).

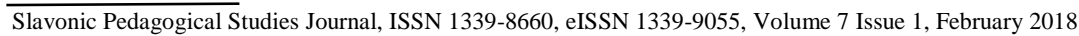


Práca v prostredí pripomína prácu filmárov (vymyslenie námetu, príprava scenára, scény, postáv, kostýmov), podporuje predstavivost', rozvíja tvorivost'. Námet na projekt sa technicky realizuje vo forme programu, ktorý sa skladá z farebných blokov inšpirovaných tvarom skladačiek puzzle, rozvíja sa algoritmické myslenie, technické zručnosti, precíznost'. Hotový projekt je možné publikovat' na webe, aby ho iní mohli komentovat', hodnotit', nahliadnut' do kódu, upravit'. Podporujú sa sociálne stránky učenia sa v digitálnom prostredí.

Práca na programátorskom projekte je príkladom projektového vyučovania (Kalas a kol., 2010), ktoré môže významne prispievat' k rozvoju kritického a tvorivého myslenia študentov:

- Študenti sa učia sami si organizovat' činnost', plánovat', rozhodovat', preberajú zodpovednost' za svoje vzdelávanie tým, že sú účastní na tvorbe zadania a spôsobe realizácie,

- $\quad$ pri práci na projekte sa vyžadujú kontextuálne vedomosti a zručnosti z viacerých oblastí (nielen z programovania), vyžaduje sa aktívna a konštruktívna práca,

- výsledky projektu sa prezentujú v užšej alebo širšej (celosvetovej) komunite (v prostredí Scratch sa publikujú, komentujú, hodnotia na webe), v prípade skupinového projektu vznikajú sociálne interakcie medzi riešitel'mi.

\section{Aktivita Multimediálny interaktívny príbeh}

V príprave študentov učitel'stva informatiky na UKF v Nitre venujeme zvláštnu pozornost' projektovému vyučovaniu zaradením špeciálneho seminára Projekty v školskej informatike v poslednom ročníku magisterského štúdia. Jedným z projektov riešených na seminári je programátorský párový projekt Multimediálny interaktívny príbeh.

Anotácia zadania: Interaktívne príbehy sú príbehy, ktorých dej sa odvíja v závislosti od vstupov používatel'a. Vstupy môžu byt' rozhodnutia, na základe ktorých sa dej vetví, alebo podnety, na základe ktorých dej pokračuje, alebo dáta, ktoré sú do deja zakomponované. Žiaci vymyslia interaktívny príbeh a implementujú ho ako multimediálnu interaktívnu prezentáciu v prostredí Scratch. Pracujú vo dvojiciach (párový projekt).

Opis výsledného produktu: Výsledkom má byt' projekt publikovaný v prostredí Scratch, ktorý obsahuje:

- grafiku: fotografie, kreslená grafika,

- zvuk: hudba, syntetické efekty, nahrané zvuky,

- text,

- $\quad$ interaktívne prvky: na posúvanie deja d'alej, na vetvenie príbehu a na vstup dát zakomponovaných do deja.

Študentky si v ukážkovom projekte na Obr. 1 zvolili tému recyklácie odpadu. Postava v projekte osloví používatel'a a interaguje s ním v krátkom rozhovore, v ktorom ho vyzve vyzbierat' a roztriedit' odpadky v byte. Dej sa vetví pomocou šípok, ktorými sa vyberá miestnost' bytu. Dej sa posúva klikaním na odpadky v izbách, po vyzbieraní všetkých sa interaktívne umiestňujú do príslušných kontajnerov. 

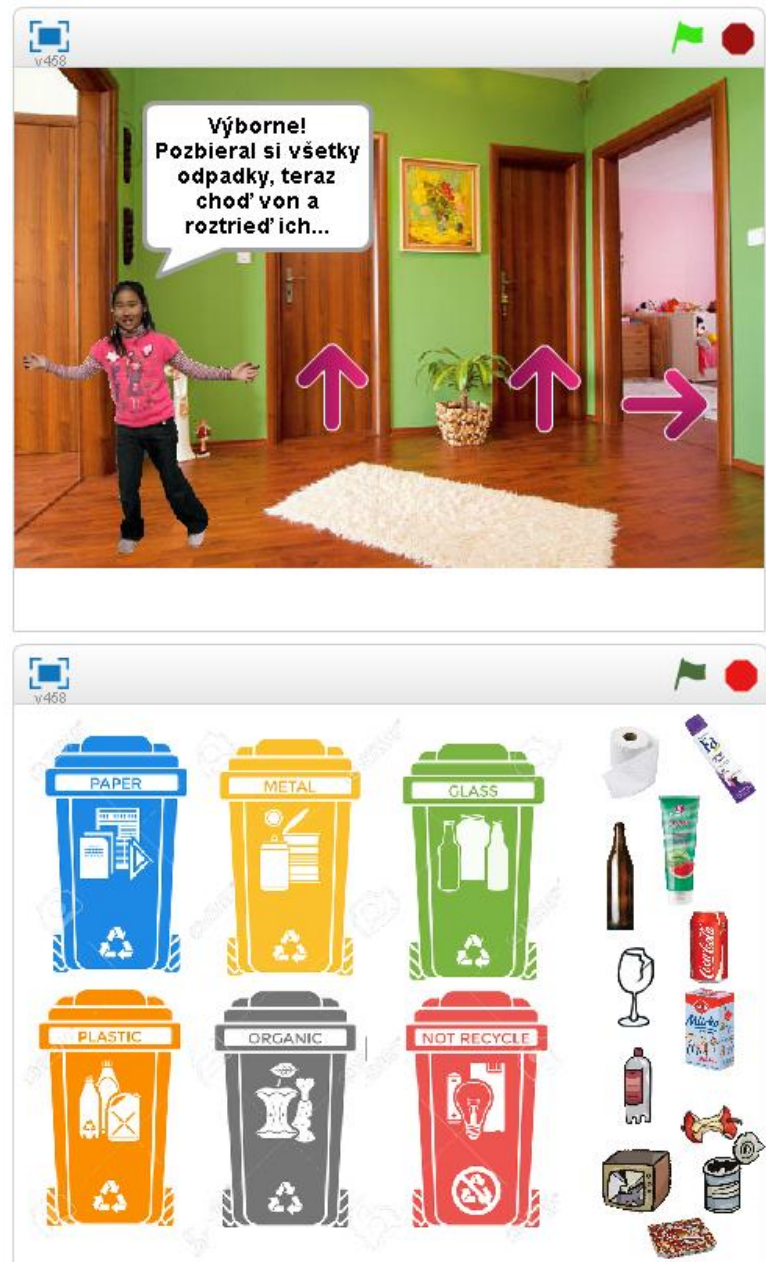

Obrázok 1 Študentský projekt Scratch: Recyklácia odpadu. (Zdroj: https://scratch.mit.edu/projects/183459955/)

Výsledný projekt spín̆a predpísané zadanie. Je spracovaný precízne do detailov, obsahuje 24 aktívnych objektov a 158 skriptov na ovládanie ich správania. Projekt má invenčný námet, ktorý úspešne zarad’uje do vyučovania informatiky prierezovú tému Enviromentálna výchova.

Príklady d’alších námetov realizovaných projektov: príbeh na tému Never cudzím l’ud’om, Športový Scratch (športové aktivity v parku), Sprievodca Nitrou (interaktívny turistický sprievodca), Išlo vajce na výpravu (interaktívna rozprávka).

\section{Práca v kolaboratívnych prostrediach}

Jednou zhlavných výziev vyučovania informatiky je zmena $\mathrm{z}$ prevažne individuálnych na kolaboratívne metódy práce. Svet je globalizovaný vd’aka digitálnemu prepojeniu a komunikácii. Nová generácia žiakov je prirodzene 
súčast'ou digitálneho sveta a vo svojom osobnom živote v ňom prirodzene komunikuje a spolupracuje. Ciel'om vyučovania informatiky je využit' tento fenomén v prospech vzdelávania a súčasne upozorňovat’ na nebezpečenstvá, ktoré v on-line prostredí vznikajú.

Hlavným znakom kolaboratívneho vzdelávania je vysoká pravdepodobnost' získania nového poznania prostredníctvom interakcie s inými l'ud'mi. Každá učebná aktivita, ktorá vytvára priaznivé podmienky pre vytváranie produktívnych interakcií medzi študentmi, môže byt' považovaná za kolaboratívnu (Dillenbourg, 1999). Rôzne on-line prostredia so sociálnymi prvkami (zdiel'anie, hodnotenie, diskusia, komunikácia), ako napríklad kancelárske on-line aplikácie (MS Office 365, Google Apps), programovacie prostredia (Scratch, App Inventor), prostredia na manažovanie elektronických kurzov (Moodle), prostredia na publikovanie výsledkov tvorivej činnosti (blogov, videí, aplikácií), takéto vhodné podmienky vytvárajú.

\section{Aktivita Kreslenie s GPS}

Kreslenie s GPS (GPS Drawing) je zaznamenanie prejdenej trasy pomocou technológie GPS a grafické zobrazenie trasy vo forme obrázka, digitálnej mapy alebo animácie. Pohyb v teréne sa naplánuje tak, aby prejdená trasa predstavovala esteticky zaujímavý obrázok. Aktivita kombinuje výtvarné umenie, fyzický pohyb $\mathrm{v}$ teréne a použivanie mobilných digitálnych technológií. Môže byt' námetom na skupinový projekt.

Anotácia projektu: GPS drawing je kreslenie obrázkov vel'kých rozmerov pomocou zaznamenávania pohybu v teréne pomocou technológie GPS. Žiaci v projekte vytvoria spoločnú mapu okolia školy (cesty, objekty), so zaujímavými obrázkami (v štruktúrovanom alebo neštruktúrovanom prostredí) pomocou záznamu pohybu v mobilnom zariadení. Projekt je skupinový.

Opis výsledného produktu: Zdiel'aná digitálna mapa so zaznamenanými trasami:

- trasa kopíruje cesty, alebo vytvára zmysluplný obrázok,

- trasy obsahujú textové informácie o trase, o autorovi, štatistické parametre trasy (dížka, čas, rýchlost', prevýšenie), fotografie z terénu. 

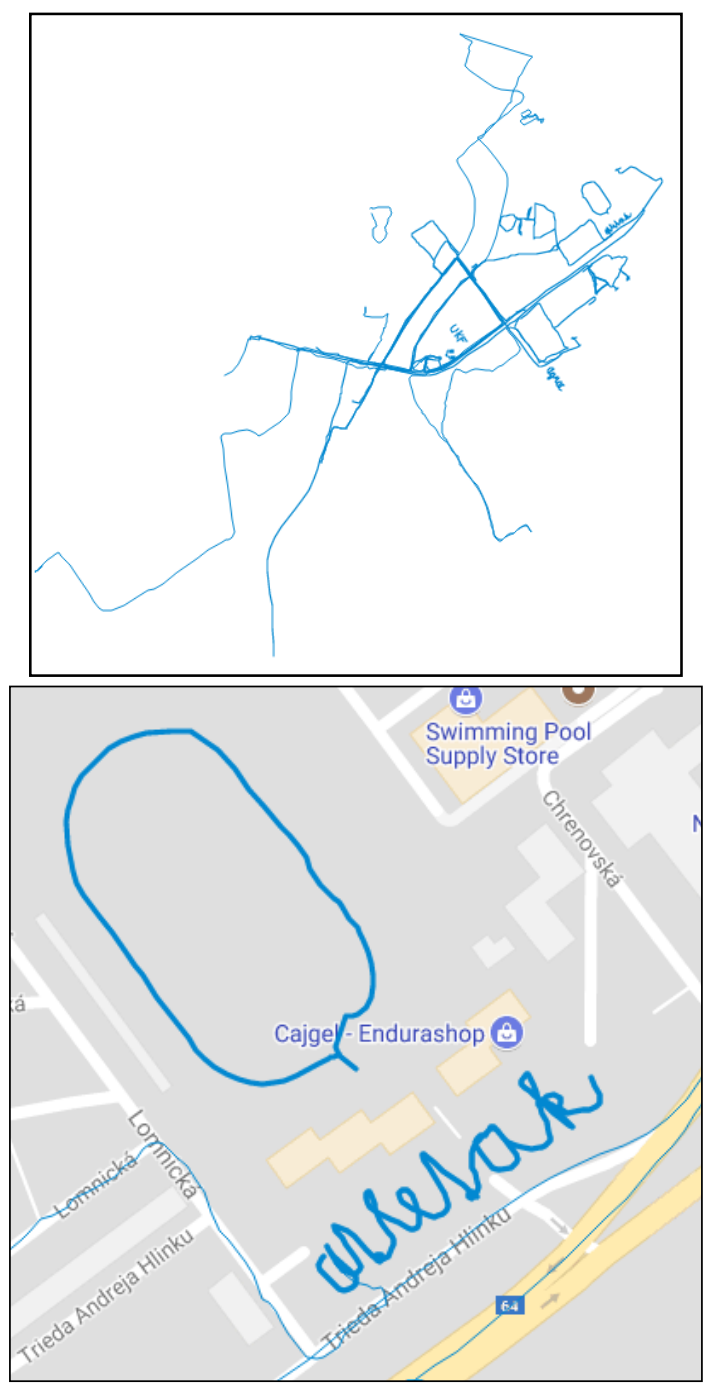

\section{Obrázok 2 Kreslenie s GPS: Študentský projekt - mapa a detail mapy}

Na Obr. 2 je mapa a detail mapy výsledného študentského projektu realizovaného na seminári Projekty v školskej informatike. Na tvorbe mapy spolupracovalo 9 študentov. Študenti najprv navrhovali svoje kresby v digitálnej mape na počítači. Pri zaznamenávaní trasy v exteriéri však boli konfrontovaní s limitmi technológie GPS a mnohé svoje návrhy museli prehodnotit', upravit'. Výsledná mapa obsahuje 25 položiek v 8 vrstvách mapy. Trasy zaznamenávali vonku pomocou mobilných zariadení. Zaznamenané dáta zobrazili v spoločne zdiel'anej mape Google. Svoje trasy doplnili požadovanými údajmi z opisu výsledného produktu (textové informácie, fotografie).

Pri tvorbe mapy vznikali rôzne formy interakcie medzi študentmi. V rámci skupiny sa prirodzene vytvorili dvojice, ktoré spolupracovali pri

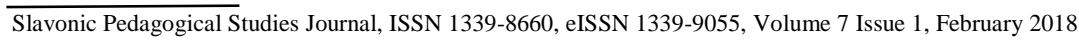


zaznamenávaní trás $\mathrm{v}$ teréne. Pri spracovávaní údajov na počítači študenti spoločne objavovali spôsoby práce s digitálnou mapou, komunikovali o výslednej podobe mapy, pomáhali si s riešením problémov. On-line prostredie Google Máp ponúka vhodné nástroje na kolaboráciu pri návrhu, spracovaní a prezentácii výsledkov projektu.

\section{Záver}

Moderná didaktika informatiky integruje v ciel'och vyučovania:

- získavanie fundamentálnych vedomostí o automatizovanom spracovaní informácií,

- nadobúdanie zručností v práci s digitálnymi technológiami,

- rozvoj informatického myslenia ako schopnosti efektívne používat' digitálne technológie na riešenie problémov,

- budovanie zdravej digitálnej identity založenej na chápaní spoločenských aspektov informatizácie.

Koncepčnými východiskami pre didaktiku informatiky voblasti metód vyučovania sú zmeny z prevažne inštruktívnych na konštruktívne, z prevažne individuálnych na kolaboratívne metódy práce a dôraz na kritické myslenie a tvorivost'. Zásadnou výzvou pre didaktiku informatiky je riešenie protikladu medzi jednoduchostou slobodného prístupu k informáciám a ich spracovania prostredníctvom digitálnych technológií a medzi zložitost'ou pochopenia a hodnotenia informácií bez predspracovania autoritou. Riešenie tohto problému si vyžaduje rozvíjanie kritického myslenia študentov, posun od povrchnosti $\mathrm{k}$ väčšej hĺbke a $\mathrm{k}$ rozmýšl'aniu v kontexte.

Rozvoj kritického myslenia $\mathrm{v}$ didaktickej príprave budúcich učitel'ov informatiky zameriavame na posilnenie kognitívnych spôsobilostí vediet' logicky usudzovat', interpretovat', analyzovat', hodnotit', vysvetl'ovat'. Príkladom sú aktivity na nácvik schopnosti štruktúrovat' a presne vyjadrit' poznatky (poznámkovanie, tvorba slovníka pojmov).

Tvorivá činnost' pozitívne vplýva na rozvoj osobnostných kvalít kriticky mysliaceho človeka. Práca na tvorivých projektoch v príprave študentov učitel'stva informatiky umožňuje využit' široký okruh záujmov, podporuje otvorenost' mysle, nezaujatost', dôveru v silu rozumu a vlastný úsudok, precíznost' a rozvíja pracovné návyky.

Za dôležité považujeme podporovat' všetky formy interakcií medzi študentmi v procese učenia sa. Interakcie, ktoré vznikajú pri kolaboratívnom učení sa, poskytujú príležitost' pre vzájomné zdiel'anie a rozširovanie skúseností študentov, pre vzájomnú konfrontáciu názorov a rozširovanie kontextov poznatkov. Študenti sa učia argumentovat', vysvetl'ovat', interpretovat', ale aj byt' opatrní pri utváraní záverov, ochotní priznat' si vlastné chyby a prehodnotit' vlastné stanovisko. Digitálne technológie poskytujú množstvo nástrojov a on-line prostredí, ktoré podporujú kolaboratívne formy práce, a pri správnej metodike môže byt' ich využívanie vel'mi prínosné pre rozvoj kritického myslenia a tvorivosti.

Príspevok vznikol v rámci riešenia projektu APVV-15-0368 Prax v centre odborovej didaktiky, odborová didaktika $\mathrm{v}$ Centre praktickej prípravy 
s podporou Agentúry na podporu výskumu a vývoja Ministerstva školstva, vedy, výskumu a športu SR.

\section{Bibliographic references}

DILLENBOURG, P. 1999. What do you mean by collaborative learning?. In P. Dillenbourg (Ed.) Collaborative-learning: Cognitive and Computational Approaches. Elsevier, Oxford, 1999. pp. 1-19.

DUCHOVICOVA, J. - TOMSIK, R. 2017. Critical and Creative Thinking Strategies in Teaching. Internal consistency of the research tool. In Slavonic Pedagogical Studies Journal, vol. 6, Issue 2, pp. 375-394

FACCIONE, P. A. 2015. Critical Thinking: What Is It and Why It Counts. [online] Measured Reasons LLC, Hermosa Beach, CA. [cit. 2017-11-30] Available online: https://www.insightassessment.com/content/.../what\&why.pdf

KALAS, I. - VANICEK, J. - MIKOLAJOVA, K. - KABATOVA, M. PEKAROVA, J. 2010. Dalsie vzdelavanie ucitelov zakladnych skol a strednych skol v predmete informatika: Digitalne technologie a zasahy do vyucovania. Bratislava : SPU, 2010. ISBN 978-80-8118-032-3

MICHALICKOVA, V. - LOVASZOVA, G. 2014. Fostering Higher-Order Thinking Skills within an Online Learning Environment. In : DIVAI 2014 : 10th International Scientific Conference on Distance Learning in Applied Informatics. Conference proceedings, Sturovo, Slovakia May 5-7, 2014 Praha : Wolters Kluwer, 2014. ISBN 978-80-7478-497-2, pp. 411-420.

RUISEL, I. 2004. Mudrost v zrkadle vekov. Bratislava : Ikar, 2005. 293 s. ISBN 80-551-1059-X

doc. RNDr. Gabriela Lovászová, PhD.

Department of Computer Science

Faculty of Natural Sciences

Cnstantine the Philosopher University

Tr. A. Hlinku 1

94901 Nitra

Slovakia

glovaszova@ukf.sk 